\title{
Right to Dignity and Human Rights: Tracing the Values from Indian Perspective
}

\author{
Ratan Singh Solanki, Bhupal Bhattacharya
}

\begin{abstract}
The present paper intends to focus on correlation of human dignity with human rights in Indian philosophical perceptive. The philosophy of India as a nation and Hinduism as a major religion sets a platform for the origin of human dignity and human rights and their correlation. In Hinduism, the importance of human dignity is evident from the fact that human beings are introduced as Amritasya Putrah Vayam - meaning thereby, we are all begotten of the immortal.
\end{abstract}

The understanding of human identity and dignity is more ethical-spiritual than material. Right from the Vedic times, an invisible Atman - the Soul; Paramaatman - the Divine whole and 'Chetna' - Universal oneness always find mention in Hindu classical thought. Lastly the ideal of Vasudhaiva Kutumbakam the whole world as One Family -also becomes unique in this age of Globalizations. In present age what we are actually achieving is not Globalization, but Mc Donaldization.

The paper is purely conceptual and only available literatures have been taken in updating the paper following the doctrinal method of study.

Index Terms: Indian Philosophy, Dignity of Human being, Human Rights, Indian Perspective

\section{INTRODUCTION}

Every individual soul is potentially divine- Swami Vivekananda. This role and value is ideal and attached to Human dignity alongwith Human rights in Indian society. Dignity of Human being is an essential concept for any society, is also a test to determine the honour and rights of the people in that society. Dignity of Human being is a base for the rights of a human being. Unless and until a person's dignity is maintained, there is no point talking about his rights. The meaning and concept of Human dignity, Human Rights are related with Atma (soul) and Parmatma (divine) and these correlates from a philosophical point of view in Indian society or to be more precise, in Hindu dominated society.

Revised Manuscript Received on July 5, 2019

Dr. R. S. Solanki, Associate Professor, Faculty of Law, Banasthali Vidyapith, Rajasthan, India.

Bhupal Bhattacharya, Assistant Professor (Scale- III), Amity Law School, Amity University Kolkata, Kolkata, India,

\section{ANCIENT THOUghtS AND Human Rights}

The life of an individual is sacred and pious because he is the focal point of God's reflection in this materialistic world. The worth and value of a human being transcends from God and thus this dignity is free from any human interference of whatsoever kind.

One can also say that Human Rights are rights occurring naturally. The theory behind such rights leads us to ancient human civilization. These rights are simply the rights which every human being enjoys being human. They are fundamental standards of life which helps an individual to live with dignity. Violating these rights is as good as not treating that person as a person, as an individual or as a human. To go for human rights in a way also means to respect the dignity of an individual If anyone has to claim these rights, it his duty not to infringe the rights of others and to stand with a person whose rights is abused or denied.

If we talk about human civilization and its history, it witnesses the efforts of mankind which always tried it's best to ensure respect for the dignity of individuals. The same history also reflects the battle of recognition of dignity and the battle of rights of an individual.

This dignity followed by rights of an individual is inseparable from an individual for being an individual person. This dignity deserved to be recognized as rights and these rights must go with the dignity of a person keeping apart other factor like one's colour, caste, or creed. Thus, we can always say that there is a correlation between Human dignity and rights of an individual and that the dignity of an individual is the essence of Human rights.

If we see the philosophy behind the dignity of an individual and his rights in Hindu dominated Indian society, Hinduism always looks for spirituality by way of morality and thus believes that there is no single ordained path for that. Whether Hinduism is a religion has always been identified as a matter of debate, Even the Apex court of India has defined it as a way of life. And so, there is nothing like religious law in Hinduism, the way it is in other religions.

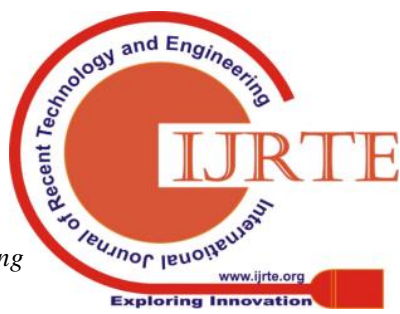




\section{Hinduism AND Human Rights}

The Hindu education system has come up with a unique model of Gurukul where the Guru is a philosopher, friend and a guide. When we see the Vedic texts, they reflect: Dharma(religion), Karma(action) \& Punarjanma (rebirth) the basic visions of mankind which are always forever and applies across the globe and across all the religions, not just limited to just Hindus. The Human dignity and Human rights in Hinduism are centered around these three visions.

In Hinduism, human beings are introduced as 'Amritasya Putrah Vayam' which means "We are all begotten of the immortal." To understand the concept and core of human dignity and human rights in Hinduism, it becomes must to understand basic fundamentals of Hindu religion which find place in old Vedas and Upanishads.

Atma a word from Sanskrit language that means 'inner-self' or 'soul' of an individual, from the time of Vedas, world's most ancient literature forms the base for having a talk on dignity and position of an individual under the ancient Hindu school of classical thought. This Atma which is considered as the base, the first step, the real self of an individual over and above any identity is the essence of an individual in Hindu philosophy, especially in the Vedanta school of Hinduism. To liberate Atma, an individual should attain Atma gyana (self-knowledge) which is realization of Atma with Brahman. According to Mundaka Upanishad, this Atma (soul) is there in every part of the Universe., Lord Krishna in battlefield of Mahabharata rightly preached Arjuna by saying. 'Mayi Sarvamidam Protam Sutre Manigana Iva' - 'I am in every part of Universe the way gems are threaded together'.

Paramatma (Divine) on the other side consists of two words, paramatma, that is "supreme" or "highest", and Atma, that is individual spirit or soul or self. Thus under Vedanta and Yoga philosophies of India , Paramatma is an absolute Atma or divine soul or spirit. One can also say that it is "Primordial Self" or the "Self Beyond" and is identical with Brahman. And so Parmatma is Creator and is Life in infinity, Life in Consciousness, and is Supreme Self or the Universal Self.

And then, it is the Chandogya Upanishad which visualizes the oneness of Atman (human being) and Paramaatma (Divine) where Universal oneness of an individual depends up on 'Chetna' - the collective consciousness. This philosophy of having union of Atma and Paramatama and the role of Chetna, the Consciousness, is considered as same for all creations in this world and is the greatest contribution of the Hindu classical thought in regard to Human dignity and Human rights.

Rights exists if gets protection. Narada Smriti, which may also be regarded as the old Hindu Constitution, provides the protection of Ruler to non-believers also. According to Dharma Kosha of Narada Smriti, "The king has to give protection to all, believers of Vedas (Naigamas) as well as non-believers of Vedas (Pashandis).To put in a nutshell, the classical Hindu thought perceives diversity across the globe as a Divine game and tries to enrich and preserve it rather than aiming for a Standardization of global culture.

Hinduism is a religion or not, might be a matter of debate, but if at all, it is a religion, it is a Religion of bliss. According to Hinduism, the Right of Happiness tops all the basic fundamental rights of all humans. The same is also evident from a sholaka from time immemorial, "Sarvepi Sukhinah Santu , Sarve Santu Niramayah ,Sarve Bhadrani Pashyantu , Ma Kaschid Dukhabhag Bhavet" which means that all human beings should be happy, should be healthy, can see all the auspicious things and remain free from grief. The essence of this sholaka clearly suggest that object of Hinduism is material well-being and happiness of all human beings with an end object of spiritual well-being of all. It is worthy to mention here that this all-important Right of Happiness find's no place in the acclaimed Universal Charter of Human Rights.

Hinduism doesn't believe in considering human beings as material one. It goes much beyond that and it is recognizing the identity of an individual by the logic of philosophy having the essence of ethics and spiritualism going beyond the scope of materialism. And this seems to be the reason for a sense of immortality and divinity in an individual in Hindu classical thought and this dignity is found in the society values (sanskara) and not in the Constitution of India.

\section{Connecting Human dignity with Right}

'Human dignity' is not a single word, rather a combination of two separate words, human and dignity, meaning thereby the position, the status of human being in the society which entitles them to respect, a self-respect. Such place of an individual in any society places an individual to the highest pedestal and indicates his value, his place and his position in society. It would not be wrong to relate origin of Human dignity to Almighty God as human being are considered as reflection of God's own image.

Every individual owes this dignity which has become such an intrinsic quality that it is unthinkable to separate it from other important aspects of an individual. The quality of a human being is to know and to 
love others. The super natural power makes a qualitative difference between human being with an animal. This dignity and very belief in dignity of an individual lays the founding pillar of morality which provides platform for law to enter the field from where legal rights originates.

Thus, it would not be wrong to say that dignity of an individual is a core value of a human being and it paves the way for human rights and for its recognition.

On the other side, Human rights are the rights of an individual. These rights belong equally to all human beings, universally and forever. These rights owe their existence because of the conditions in which human is put in. They constitute the common language of "humanity". The specialty about these rights is that they are not meant for State. Thus, these rights do not depend upon the mercy of an individual or of the State and at the same time cannot be withdrawn by them. The beneficiaries of human rights are individuals and State is under the obligation to fully protect these rights. Moreover, these rights touch the socio economic and cultural rights and are not limited to political or civil interferences

In that sense the modern thinkers are not the first to talk about the welfare and happiness of the human beings. The principle of 'Maximum Benefit to Maximum Number' based on modern economic thought has never been appreciated by the ancient Hindu seers as their idealism of life is based on 'Total Good of All Beings'.

\section{Conclusion}

To end with, the 'so called' secular ideals seems to fail in front of the Hindu ideal of 'Sarva Dharma Samabhav''Equal Respect for all Religions'. When the secular idealism talks for tolerating the diversity, Hinduism goes in depth by accepting every religion, not merely tolerating them, and that diversity becomes a matter of joy and celebration.

The philosophy of Hinduism suggests that it is the dignity of an individual which is a foundation stone for the rights of an individual and unless we recognize this dignity, the rights of human are unthinkable. Thus, in India it is Vedas, Upanishads and their philosophy which has paved the way for Human dignity and Human rights. To quote J. Bhagwati, "These Fundamental Rights represent the basic values cherished by the people of this country since the Vedic times and they are calculated to protect the dignity of the individual and create conditions in which every human being can develop his personality to the fullest extent".
The Sanskrit phrase from Maha Upanishad, 'Vasudhaiva Kutumbakam' -whole of the world is one family holds good worth in the era of Globalization with only difference that, today's global pundits treat whole of the world, not as a family but as a huge market. Thus, Hinduism stands for Unified World, the Globalization stands for Unified Market. In reality what we perceive as Globalisation, is nothing but Mc Donaldization which lacks not only the dignity and rights of a human being but humanity itself.

\section{ACKNOWLEDGMENT}

The authors acknowledge the immense support extended by Prof. Harsh Purohit, Dean, Faculty of Law, Banasthali Vidyapith in completing this paper.

\section{REFERENCES}

1. Ahmad, I., Ghosh, P. S., \& Reifeld, H. (Eds.). (2000). Pluralism and Equality: Values in Indian Society and Politics. SAGE Publications India. 2. Arendt, H. (2013). The human condition. University of Chicago Press.

3. Barth, K. (1960). The humanity of God. Westminster John Knox Press.

4. Benhabib, S. (2012). Is there a human right to democracy? Beyond interventionism and indifference. In Philosophical Dimensions of Human Rights (pp. 191-213). Springer, Dordrecht.

5. Bhargava, R. (2007). The distinctiveness of Indian secularism. The Future of Secularism, Oxford University Press, New York.

6. Bhatia, V. P. (2017). The Upanishads Demystified: Ethical values. Notion Press.

7. Bhawuk, D. P. (2012). India and the culture of peace: Beyond ethnic, religious, and other conflicts. In Handbook of ethnic conflict (pp. 137-174). Springer, Boston, MA

8. Bishop, T., \& Grau, D. (Eds.). (2018). Ways of Re-thinking Literature. Routledge.

9. Broughton, R., up as a Flower, C., Good-bye, S., Nancy, J., but too Well, N. W., Norris, W., ... \& Max, U. (1891). Messrs. Methuen's new books. R. Pryce. The quiet mrs. Fleming. By Richard TRYCE. Crown 8vo,.'is. $6 \mathrm{~d}$. [Ready. The Academy and Literature, 39, 248.

10. Brownsword, R. (2002). An interest in human dignity as the basis for genomic torts. Washburn LJ, 42, 413.

11. Chesler, P. (2018). Women and madness. Chicago Review Press.

12. Corbridge, S., \& Harriss, J. (2013). Reinventing India: Liberalization, Hindu nationalism and popular democracy. John Wiley \& Sons.

13. Dembour, M. B. (2010). What are Human Rights-Four Schools of Thought. Hum. Rts. Q., 32, 1.

14. Donnelly, J. (2013). Universal human rights in theory and practice Cornell University Press.

15. Feinberg, J., \& Narveson, J. (1970). The nature and value of rights. The Journal of Value Inquiry, 4(4), 243-260.

16. Feuerstein, G. (2014). The Hindu Experience and Perspective. The World's Great Wisdom: Timeless Teachings from Religions and Philosophies, 87.

17. Flowers, N. (2000). The Human Rights Education Handbook: Effective Practices for Learning, Action, and Change. Human Rights Education Series, Topic Book. Human Rights Resource Center, University of Minnesota, 229 19th Avenue South, Room 439, Minneapolis, MN 55455.

18. Galanter, M. (1971). Hinduism, secularism, and the Indian judiciary. Philosophy East and West, 21(4), 467-487.

19. Glensy, R. D. (2011). The right to dignity. Colum. Hum. Rts. L. Rev., 43, 65.

20. Glensy, R. D. (2011). The right to dignity. Colum. Hum. Rts. L. Rev., 43, 65.

21. Gore, M. S. (1997). Unity and Differentiation.

22. Hanegraaff, W. J. (1996). New age religion and western culture: Esotericism in the mirror of secular thought (Vol. 72). Suny Press.

23. Hinduism is a way of life: Firth, S. (2005). End-of-life: a Hindu view. The Lancet, 366(9486), 682-686.

24. Lebech, M. (2004). What Is Human Dignity? Maynooth Philosophical Papers. 
25. Lebech, M. (2004). What is human dignity?. Maynooth philosophical papers, 2, 59-69.

26. Mason, R. A. (Ed.). (2018). John Knox and the British Reformations. Routledge.

27. Mason, R. A. (Ed.). (2018). John Knox and the British Reformations. Routledge.

28. Moses, O. M. Inter-religious dialogue

29. Motwani, K. (1934). Manu: A study in Hindu social theory. Ganesh and Company, Madras.

30. Motwani, K. (1934). Manu: A study in Hindu social theory. Ganesh and Company, Madras.

31. Nussbaum, M. C. (2001). Women and human development: The capabilities approach (Vol. 3). Cambridge University Press.

32. Osler, A., \& Starkey, H. (2017). Teacher education and human rights. Routledge.

33. Parekh, B. C. (1989). Gandhi's political philosophy: A critical examination. Springer.

34. Radhakrishnan, S. (1926). Hindu view of life. George Allen And Unwin Ltd, London.

35. Rorty, R. (1993). Human rights, rationality, and sentimentality. Wronging Rights?: Philosophical Challenges for Human Rights, 1-34.

36. Satpathy, G. Value Education: Relevance of Gandhian Concept. DDCE, UTKAL UNIVERSITY, BHUBANESWAR, INDIA.

37. Sharma, M. (2017). Caste and nature: Dalits and Indian Environmental Policies. Oxford University Press.

38. Singer, P. (Ed.). (2013). A companion to ethics. John Wiley \& Sons.

39. Sinha, M. K. (2005). Hinduism and international humanitarian law. International Review of the Red Cross, 87(858), 285-294.

40. Stern, J. (2018). Teaching religious education: Researchers in the classroom. Bloomsbury Publishing.

41. Subedi, S. P. (1999). Are the Principles of Human Rights Western Ideas-An Analysis of the Claim of the Asian Concept of Human Rights from the Perspectives of Hinduism. Cal. W. Int'l LJ, 30, 45.

42. Taylor, C. (1999). Conditions of an unforced consensus on human rights. The politics of human rights, 101-119.

43. Varma, P. K. (2005). Being Indian: the truth about why the twenty-first century will be India's. Penguin Books India.

\section{AUTHORS PROFILE}

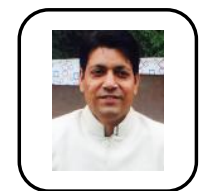

\section{Dr. R. S. Solanki}

Dr. R. S. Solanki is presently associated with Faculty of Law, Banasthali Vidyapith in the capacity of Associate Professor in Law. He has completed his B.Com, LL.M., Ph.D.. He is known as a very popular author in legal field. $\mathrm{He}$ has authored two books namely Law \& Financial reforms in Insurance Sector- Reforms \& Regulations and another on Banking Law. One of his research papers "Go clean Go Green: E Banking and its sustainability" was recently listed on SSRN's Top Ten download list for: eBusiness \& E-Commerce eJournal, June 2019.

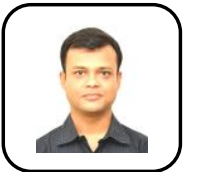

Bhupal Bhattacharya

Bhupal Bhattacharya is presently associated with Amity Law School, Amity University Kolkata as a Faculty member. He has more than 9.5 years of academic experience in different institutions including Banasthali Vidyapith, NIT Durgapur, Amity University Mumbai, Sikkim Manipal University, etc., in addition to 2 years of industrial experience. He has completed his B.com (Hons.), LL.M, MSW and has submitted his Ph.D. thesis for the award. He is in the editorial boards of many national and international Journals. He has to his credits four books published (two from Indian Publishers and rest other two from an Australian Publisher) in addition to few published research papers in various Scopus indexed international journals. 